\title{
THE COMPARATIVE LEGAL ANALYSIS OF THE SOURCES OF THE ELECTORAL RIGHTS OF FOREIGN CITIZENS AT THE MUNICIPAL LEVEL IN THE RUSSIAN FEDERATION AND THE REPUBLIC OF KOREA Kuznetsova N. СРАВНИТЕЛЬНО-ПРАВОВОЙ АНАЛИЗ ИСТОЧНИКОВ ИЗБИРАТЕЛЬНОГО ПРАВА ИНОСТРАННЫХ ГРАЖДАН НА УРОВНЕ МУНИЦИПАЛЬНОГО ОБРАЗОВАНИЯ В РОССИЙСКОЙ ФЕДЕРАЦИИ И РЕСПУБЛИКЕ КОРЕЯ Кузнецова Н. О.
}

\author{
Кузнецьва Наталья Олеговна / Kuznetsova Natalia-магистрант, \\ направление: юрист в сфере публичного права, \\ Юридическая школа \\ Дальневосточный федеральный университет, г. Владивосток
}

\begin{abstract}
Аннотация: данная статья посвящена анализу источников избирательного права иностранных граждан в Российской Федерации. Автор при анализе нормативно-правовых актов приходит к выводу, что нормативно-правовая основа избирательного права иностранных граждан в Республике Корее более развита, чем в Российской Федерачии. Автор приходит к выводу о том, что нужно внести поправки в законь Российской Федерации, нужно более эффективное законодательное регулирование, данный опыт может быть применён в Российской Федерации с учётом его адаптации на внутреннее право государства.

Abstract: this article is devoted to the analysis of the sources of the electoral rights of foreign citizens in the Russian Federation. By the analysis of legal acts to come to the conclusion that the legal framework of the electoral rights of foreign nationals in the Republic of Korea is more developed than in the Russian Federation. The author comes to the conclusion that it is necessary to amend the Law of the Russian Federation in need of a more effective legal regulation, this experience can be applied in the Russian Federation in view of its adaptation to the domestic law of the state.
\end{abstract}

Ключевые слова: избирательное право, иностранные граждане, депутаты, кандидаты, статус, постоянно проживающие, избирательная кампания.

Keywords: the electoral right, foreign citizens, deputies, candidates, the status which is constantly living, the election campaign.

В настоящее время развитие миграционного потока в мировом масштабе оказывает огромное влияние на современное экономическое, социальное, культурное и политическое развитие человечества. В 2013 г., согласно оценкам Всемирного банка, уточнённым по данным переписей населения раунда 2010 г., общее число мигрантов в мире составляло 247 млн и ожидалось, что в 2015 г. оно превысит 250 млн человек [1]. В каждой стране иностранные граждане имеют ограниченные избирательные права, в основном их наделяют избирательными права на муниципальном уровне.

Нормативно-правовой базой избирательные права иностранных граждан закреплены: в ч. 10 ст. 4 Федерального закона от 12 июня 2002 г. № 67-Ф3 «Об основных гарантиях избирательных прав и права на участие в референдуме граждан Российской Федерации» (ред. от 6 апреля 2015 г.) устанавливается, что «на основании международных договоров Российской Федерации и в порядке, установленном законом, иностранные граждане, постоянно проживающие на территории соответствующего муниципального образования, имеют право избирать и быть избранными в органы местного самоуправления, участвовать в иных избирательных действиях на указанных выборах, а также участвовать в местном референдуме на тех же условиях, что и граждане РФ» [2], подтверждающие права иностранцев на участие в муниципальных выборах, также является: во-первых, в ч. 2 ст. 12 Федерального закона от 25 июля 2002 г. № 115-Ф3 «О правовом положении иностранных граждан в Российской Федерации» [3] закрепляется право постоянно проживающих в России иностранных граждан избирать и быть избранными в органы местного самоуправления, а также участвовать в местном референдуме в случаях и порядке, которые предусмотрены федеральными законами. Во-вторых, в п. 1 ст. 3 Федерального закона от 6 октября 2003 г. № 131-Ф3 «Об общих принципах организации местного самоуправления в Российской Федерации» [4] устанавливается, что «иностранные граждане, постоянно или преимущественно проживающие на территории муниципального образования, обладают при осуществлении местного самоуправления правами в соответствии с международными договорами Российской Федерации и федеральными законами». Согласно международным договорам, заключённым Российской Федерацией с иностранными государствами: 
- правом голосовать на выборах главы муниципального образования, на выборах в представительные органы муниципальных образований, правом на участие в местном референдуме обладают постоянно проживающие на территории муниципального образования граждане Киргизской Республики, а также граждане Туркменистана и Республики Беларусь;

- быть избранными в представительные органы местного самоуправления и главой муниципального образования могут постоянно проживающие на территории муниципального образования граждане Туркменистана и Республики Беларусь, а граждане Киргизской Республики могут быть избранными только в представительные органы местного самоуправления.

Согласно пункту 1 статьи 15 «Закона об избрании публичных должностных лиц» избирательные права предоставляются только корейскому гражданину в возрасте 19 лет на выборах президента и Национального собрания, но не позволяют иностранцем голосовать на таких выборах. Это происходит из-за озабоченности, что, если иностранцам предоставляют избирательные права, то они могут голосовать за свои интересы, а не в интересах всех людей, которые проживают на территории РК. Законодательными актами Республики Кореи предоставило избирательные права для иностранных граждан на выборах федерального значения и местного самоуправления. Однако перед государством возникла проблема, когда супруг или ребёнок кандидатов, баллотирующихся на выборах, являются иностранцами, они не могут голосовать за их супруга и родителей [5].

Согласно статье 5 «Закона о местном референдуме», иностранные граждане в возрасте 19 лет, чье место жительства зарегистрировано в данном местном самоуправлении, с постоянным местом жительства, наделены правом голосовать. Органы местного самоуправления предоставляют право иностранцам участвовать в местном сходе граждан, где каждый житель должен выразить мнение о главных проблемах и политике в месте их проживания с 19-летнего возраста в течение не менее 2 лет. Участвовать в выборах в местные органы власти, в которых иностранцам позволено голосовать и выбирать кандидата, допустимо после 3 лет постоянного проживания на данной территории.

Право голосовать по вопросу отзыва предоставляется иностранным гражданам, если они соответствуют следующим критериям: старше 19 лет; проживают в соответствующий административнотерриториальной единице не менее трех лет; зарегистрированы в местном реестре иностранных граждан.

Иностранные граждане, даже имеющие статус постоянно проживающего на территории РК, не имеют прав при формировании центральных органов власти.

Пункт 2 этой же статьи был пересмотрен в 2005 году, чтобы предоставить право голосования на выборах в местные органы власти иностранцам, которые достигли возраста 19 лет и проживали в Корее больше чем три года после получения права на постоянное проживание в стране.

Когда проходят выборы в муниципальном образовании происходит информационное обеспечение выборов, но не каждый иностранец, который обладает избирательным правом, знает, как и где проходят выборы. Информационное обеспечение иностранцев в России не развито, лишь есть малые отголоски такого информационного обеспечения. К примеру, в информационном сообщении, размещенном на сайте избирательной комиссии Тюменской области 03.04.2011 года, указано: Избирательная комиссия Тюменской области информирует о том, что в настоящее время на выборах депутатов представительных органов муниципальных образований пассивным и активным избирательным правом обладают постоянно проживающие на территории Российской Федерации граждане Киргизской Республики, Туркменистана и Республики Беларусь. 03.03.2011 года на сайте избирательной комиссии Амурской области был опубликован ответ на вопрос: «Имеют ли право иностранные граждане участвовать в выборах в органы местного самоуправления?» [6].

Для решения данной проблемы можно использовать опыт Республики Корея, где для привлечения иностранных граждан к голосованию принимаются следующие меры:

для постоянно проживающих жителей-не корейцев, обладающих избирательными правами, но никогда не голосовавших в Корее, центральные избирательные власти заявили, что они проводят практику сессий голосования и издают собственные разъяснительные брошюры о том, как голосовать, на китайском, английском и вьетнамском языках для того, чтобы помочь избирателям с мультикультурной основой или не корейцам, проживающим в стране; до избирателей доводят информацию о предстоящих выборах посредством радио- и он-лайн-трансляций; проводятся лекции, а также, будучи показываемыми по местным телепрограммам, они подчеркивают важность участия в выборах, в особенности для избирателей из мультикультурных семей [7].

Из вышесказанного можно сделать следующий вывод: в законодательстве Российской Федерации имеется следующее противоречие: в законодательстве требования к иностранным гражданам в избирательном праве противоречат друг другу, для решения данной проблемы нужно четко сформировать данное требование. В Республике Корея избирательные права иностранных граждан более развиты, в РФ иностранцы могут быть избраны и избираться только на основании законодательства или заключением международного договора, в РК такое право дается всем гражданам, которые соответствуют данным требованиям. 
Опыт избирательного права иностранных граждан в Республике Корее может быть полезен для Российской Федерации с учетом их экономических, культурных, политических и социальных особенностей. Полагаем необходимым расширение двустороннего сотрудничества между Российской Федерацией и Республикой Корея по вопросам избирательных прав.

\section{Лuтература}

1. Migration and Development Brief 24. World Bank, 13 апреля 2015.

2. Об основных гарантиях избирательных прав и права на участие в референдуме граждан Российской Федерации: Федер. закон от 22.05.2002 № 67-Ф3 // Собр. Законодательства Рос. Федерации, 2002. № 24. Ст.2 253 (с посл. изм. и доп. от 05.04.2016).

3. О правовом положении иностранных граждан в Российской Федерации: Федер. закон от 25.07.2002 № 11-Ф3 // Собр. Законодательства Рос. Федерации, 2002. № 30. Ст. 3032 (с посл. изм. и доп. от 31.07.2016).

4. Об общих принципах организации местного самоуправления в Российской Федерации: федер. закон от 06.10.2003 №131-Ф3 // Собр. Законодательства Рос. Федерации, 2003. № 40. Ст. 3822 (с посл. изм. и доп. от 03.07.2016).

5. Public Official Election Act (Закон об избрании публичных должностных лиц). № 4739 от 1994 г. [Электронный ресурс]. Режим доступа: National law information center/ (дата обращения: 20.01.2017).

6. Избирательное права иностранных граждан. 2013. [Электронный ресурс]. Режим доступа: http://lehut.livejournal.com/48860.html/ (дата обращения: 21.12.2016).

7. Кузнецова Н. О. Избирательное право иностранных граждан в законодательстве Республике Корея / Н. О.Кузнецова // Проблемы современной науки и образования, 2016. № 17(59). С. 91-92. 